\title{
Microstructure and Martensitic Transformation Behavior in Thermal Cycled Equiatomic CuZr Shape Memory Alloy
}

\author{
Shota Hisada ${ }^{1}$, Mitsuhiro Matsuda ${ }^{2, *}$, Minoru Nishida ${ }^{3}$, Carlo Alberto Biffi ${ }^{4}$ \\ and Ausonio Tuissi ${ }^{4}$ \\ 1 Department of Materials Science and Engineering, Kumamoto University, Kumamoto 860-8555, Japan; \\ 172d9204@st.kumamoto-u.ac.jp \\ 2 Division of Materials Science and Chemistry, Faculty of Advanced Science and Technology, Kumamoto \\ University, Kumamoto 860-8555, Japan \\ 3 Department of Advanced Materials Science and Engineering, Faculty of Engineering Sciences, Kyushu \\ University, Fukuoka 816-8580, Japan; nishida.minoru.355@m.kyushu-u.ac.jp \\ 4 National Research Council of Italy, Institute of Condensed Matter Chemistry and Technologies for Energy, \\ CNR ICMATE Lecco, Via G. Previati, 23900 1/E Lecco, Italy; carloalberto.biffi@cnr.it (C.A.B.); \\ ausonio.tuissi@cnr.it (A.T.) \\ * Correspondence: matsuda@alpha.msre.kumamoto-u.ac.jp; Tel.: +81-96-342-3718; Fax: +81-96-342-3710
}

Received: 30 April 2019; Accepted: 16 May 2019; Published: 18 May 2019

\begin{abstract}
Equiatomic CuZr alloy undergoes a martensitic transformation from the B2 parent phase to martensitic phases $\left(P 2_{1} / \mathrm{m}\right.$ and $\left.\mathrm{Cm}\right)$ below $150{ }^{\circ} \mathrm{C}$. We clarified the effect of the thermal cycling on the morphology and crystallography of martensite in equiatomic $\mathrm{CuZr}$ alloy using a transmission electron microscopy. The 10th cycled specimens consisted of different multiple structures at the maximum temperature of differential scanning calorimetry (DSC) measurement $-400{ }^{\circ} \mathrm{C}$ and $500{ }^{\circ} \mathrm{C}$, respectively. At the maximum temperature $400{ }^{\circ} \mathrm{C}$ of DSC measurement, it is composed of the fine plate-like variants, and a lamellar eutectoid structure consisting of $\mathrm{Cu}_{10} \mathrm{Zr}_{7}$ and $\mathrm{CuZr}_{2}$ phases on the martensitic variant. Concerning the maximum temperature of $500{ }^{\circ} \mathrm{C}$ of DSC measurement, it is observed the martensitic structure and the lamellar structure in which the martensitic phase was completely eutectoid transformed. The formation of this lamellar eutectoid structure, due to thermal cycling leads to the shift of forward and reverse transformation peaks to low and high temperature side. In addition, new forward and reverse transformation peaks indicating a new transformation appeared by thermal cycling, and the peaks remained around $-20{ }^{\circ} \mathrm{C}$. This new martensitic transformation behavior is also discussed.
\end{abstract}

Keywords: shape memory alloys; CuZr alloy; thermal cycling; microstructure; martensitic transformation; transmission electron microscopy

\section{Introduction}

Near equiatomic Ti-Ni alloys are widely used as a shape memory alloy in the industrial and the medical fields. However, Ti-Ni alloy has a martensitic transformation near room temperature, the usable range is limited. In recent years, development of a new shape memory alloy that can be used even in a high temperature range is desired. Equiatomic $\mathrm{CuZr}$ alloy is expected as a high temperature shape memory material, since it undergoes martensitic transformation point over $100{ }^{\circ} \mathrm{C}$ [1-11]. This alloy shows a martensitic transformation from the B2 matrix (space group: $P m \overline{3} m$ ) to the two martensitic phases (space group: $P 2_{1} / m$ and $\mathrm{Cm}$ ) at about $150{ }^{\circ} \mathrm{C}$, and its reverse transformation temperature is around $265{ }^{\circ} \mathrm{C}[3-5]$. One of the important characteristics required for practical 
application of shape memory alloy is a thermal cycling property. Koval et al. [3] reported the thermal cycling behavior of equiatomic CuZr alloy is what the transformation peaks shifted significantly, and additional peaks meaning new martensitic transformation appeared by electrical resistivity measurements. In addition, Biffi et al. [12] also investigated the thermal cycling property in detail on equiatomic $\mathrm{CuZr}$ alloy by differential scanning calorimetry (DSC) measurement as follows. The thermal cycling of equiatomic $\mathrm{CuZr}$ alloy provides that the reverse transformation start $\left(A_{\mathrm{s}}\right)$ temperature and the martensitic transformation start-temperature $\left(M_{\mathrm{s}}\right)$ shifted to the high and low temperature sides, respectively. It was also confirmed that the reverse transformation peak $A$ and the martensitic transformation peak $M$ disappear in the 7th cycle [12]. Alternatively, at the 4 th cycle, new peaks $A^{*}$ and $M^{*}$ different from peaks $A$ and $M$ appeared, and then these new peaks remained around $-20{ }^{\circ} \mathrm{C}$ at the 50th cycle. Although the changes in the macroscopic features and crystal structure accompanying these peaks have been investigated by scanning electron microscopy (SEM) observation and X-ray diffraction (XRD) measurement at varying the temperature, a detail microstructural characterization is not performed in nanoscopic scale. In this study, we aimed to clarify the effect of the thermal cycling on the morphology and crystallography of martensite in equiatomic $\mathrm{CuZr}$ alloy using a transmission electron microscopy (TEM).

\section{Materials and Methods}

Equiatomic CuZr alloy was prepared from pure copper (99.99\%) and zirconium (99.2\%) by arc melting in an argon atmosphere. The button ingots with $25 \mathrm{~mm}$ in diameter and about $8 \mathrm{~mm}$ in thickness were re-melted for eight times. The samples were homogenized in an argon quartz tube at $850{ }^{\circ} \mathrm{C}$ for $10 \mathrm{~h}$, and annealed at $800^{\circ} \mathrm{C}$ for $1 \mathrm{~h}$, followed by water-quenching. After that, the disc-shaped samples with a thickness of $500 \mu \mathrm{m}$ to $1 \mathrm{~mm}$ were processed to a diameter of $3 \mathrm{~mm}$ by ultrasound machining (SBT380, meiwafosis, Osaka, Japan), and DSC measurement was performed ten times using a calorimeter (DSC 3500 Sirius, NETZSCH, Selb, Germany). The heating and cooling rates were $20{ }^{\circ} \mathrm{C} / \mathrm{min}$, and the ranges of measurement temperature were $-100{ }^{\circ} \mathrm{C}$ to $550{ }^{\circ} \mathrm{C}$. The constituent phases were examined by using an X-ray diffractometer (XRD, Smart Lab, Rigaku, Japan) with Ni-filtered Cu $\mathrm{K} \alpha$ radiation (a combination of $\mathrm{K} \alpha 1$ and $\mathrm{K} \alpha 2$, removing $\mathrm{K} \beta$ ). For TEM studies, the samples ground to a thickness of $50 \mu \mathrm{m}$, were dimpled with a GATAN Model 656, and Ar-ion milled with a GATAN model 695 PIPSII. TEM observation was carried out with a JEM- 2100 PLUS (JEOL, Akishima, Japan), which was operated at $200 \mathrm{kV}$. The selected area diffraction patterns were taken through normal diffraction modes using the aperture with a physical diameter of $10 \mu \mathrm{m}$.

\section{Results and Discussions}

\subsection{The Crystal Structure and Microstructural Feature of the Water-Quenched Equiatomic CuZr Alloy}

In order to determine the lattice constants and the constituent phases in the water-quenched equiatomic $\mathrm{CuZr}$ alloy, we performed XRD measurements. The analysis by Reference intensity ratio method [13] using the results of XRD measurement showed that the volume fraction of each phase in water-quenched equiatomic CuZr alloy is CuZr: $84 \%\left(C m: 64 \%, P 2_{1} / m: 20 \%\right), \mathrm{Cu}_{10} \mathrm{Zr}_{7}: 8 \%, \mathrm{CuZr}_{2}: 1 \%$, and $\mathrm{Cu}_{2} \mathrm{Zr}_{4} \mathrm{O}: 7 \%$. The quantitative ratio of $\mathrm{CuZr} \mathrm{Cm:} P 2_{1} / m$ is about 3:1, being almost consistent with the previous research $[9,14]$. In addition, the refinement of the lattice constants by Pawley method [15] using the results of XRD measurement provides that the lattice constants of $\mathrm{CuZr} \mathrm{Cm}$ and $P 2_{1} / m$ is $a=0.6336 \mathrm{~nm}, b=0.8589 \mathrm{~nm}, c=0.5311 \mathrm{~nm}, \beta=105.1^{\circ}$, and $a=0.3309 \mathrm{~nm}, b=0.4209 \mathrm{~nm}, c=0.5253 \mathrm{~nm}$, $\beta=104.2^{\circ}$. It showed good agreement with the previous study [3-5].

TEM observations were performed to investigate the microstructural feature and the crystal structure. Figure 1a,b shows the typical bright field images of the water-quenched equiatomic $\mathrm{CuZr}$ alloy. Martensitic variants with the plate-like morphology of $250 \mathrm{~nm}$ in average width are clearly observed in Figure 1a. The electron diffraction pattern in Figure 1c taken from the boundary $\mathrm{C}$ between martensitic variants in (a) consists of two sets of reflections from the $[100]_{C m}$ zone axis that are in 
mirror symmetry with respect to the $(02 \overline{1})_{C m}$ plane, which is parallel to the interface of alternate plates in (a). This fact indicates that those plates are in $(02 \overline{1})_{C m}$ twin relations. In Figure $1 \mathrm{~b}$, there were also the fine martensitic variants having the width of about $30 \mathrm{~nm}$ within the plate-like morphology. The electron diffraction pattern in Figure $1 \mathrm{~d}$ taken from the fine martensitic variant boundary $\mathrm{D}$ in $(\mathrm{b})$ consists of two sets of reflections from the $[110]_{\mathrm{Cm}}$ zone axis that are in mirror symmetry with respect to the $(001)_{C m}$ plane, which is parallel to the interface of alternate plates in (b). This indicates that those plates are in $(001)_{C m}$ twin relations. Those $(02 \overline{1})_{C m}$ and $(001)_{C m}$ twins are defined as the Type I and compound twins, respectively $[4,5,9]$. The lattice constant estimated by electron diffraction patterns showed a value close to the one calculated by XRD. In the TEM observation of the water-quenched equiatomic $\mathrm{CuZr}$ alloy, the amount of $P 2_{1} / m$ structure was small and was not recognized in this study.
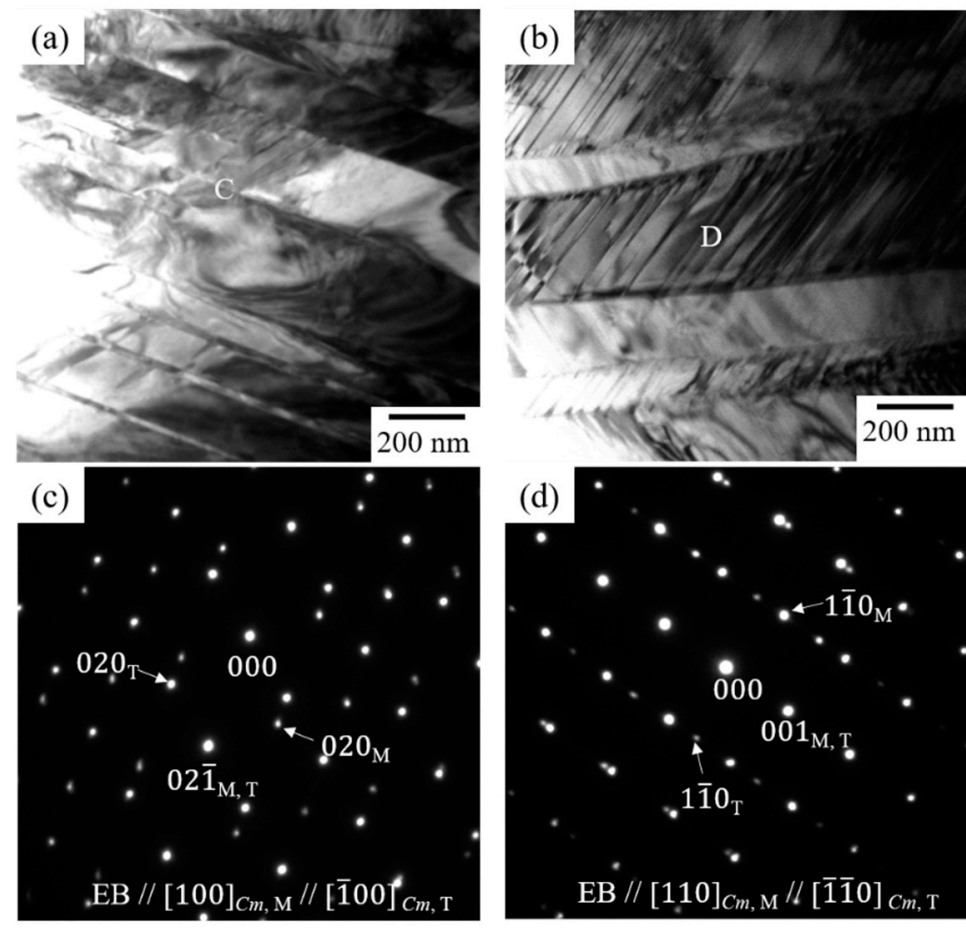

Figure 1. (a,b) Bright field images of water-quenched equiatomic $\mathrm{CuZr}$ alloy, and (c,d) electron diffraction patterns taken from the boundary $\mathrm{C}$ between martensitic variants in (a), and from the fine martensitic variants boundary D within the plate-like morphology in (b), respectively.

\subsection{Effect of Thermal Cycling on the Microstructure in Equiatomic CuZr Alloy}

Figure 2 shows the results of thermal cycling test in the water-quenched equiatomic $\mathrm{CuZr}$ alloy by using DSC measurement. The ranges of measurement temperature were $-100{ }^{\circ} \mathrm{C}$ to $400{ }^{\circ} \mathrm{C}$. The transformation start-temperature and the finish-temperature were both defined based on the intersection points of the baseline and the tangent at the inflection point. In Figure 2, there is an exothermic peak during cooling and an endothermic peak during heating. These peaks indicate that $M_{\mathrm{s}}$ and $A_{\mathrm{s}}$ are $135{ }^{\circ} \mathrm{C}$ and $261^{\circ} \mathrm{C}$ in the water-quenched equiatomic $\mathrm{CuZr}$ alloy, which are almost the same as in the previous reports $[3,12]$. As the number of cycles increases, the peaks $A$ and $M$ shifted toward the high and low temperature side, respectively, as shown in Figure 2. Also, the areas of both peaks became smaller. At the 6th cycle in Figure 2, a pair of new endothermic $A^{*}$ and exothermic $M^{*}$ peaks appeared that would indicate reverse transformation and normal transformation, respectively. As the number of cycles increased, the areas of the new peaks increased, and the areas of $A^{*}$ and $M^{*}$ in the 10 th cycle were estimated to be $-3.01 \mathrm{~J} / \mathrm{g}$, and $2.01 \mathrm{~J} / \mathrm{g}$, respectively. In the previous study [12], the new peaks appeared at the 4 th cycle, and the areas of both peaks $A^{*}$ and $M^{*}$ were $3.5 \mathrm{~J} / \mathrm{g}$, resulting in slightly different from this study. This should be due to slight differences in the ranges of measured 
temperature and rates; previous study: -100 to $450{ }^{\circ} \mathrm{C}, 10{ }^{\circ} \mathrm{C} / \mathrm{min}$, present study: -100 to $400{ }^{\circ} \mathrm{C}$, $20^{\circ} \mathrm{C} / \mathrm{min}$. There was no significant difference compared with a shift of the peaks $A$ and $M$, and the appearance of new peaks $A^{*}$ and $M^{*}$, due to the thermal cycling in the previous study.

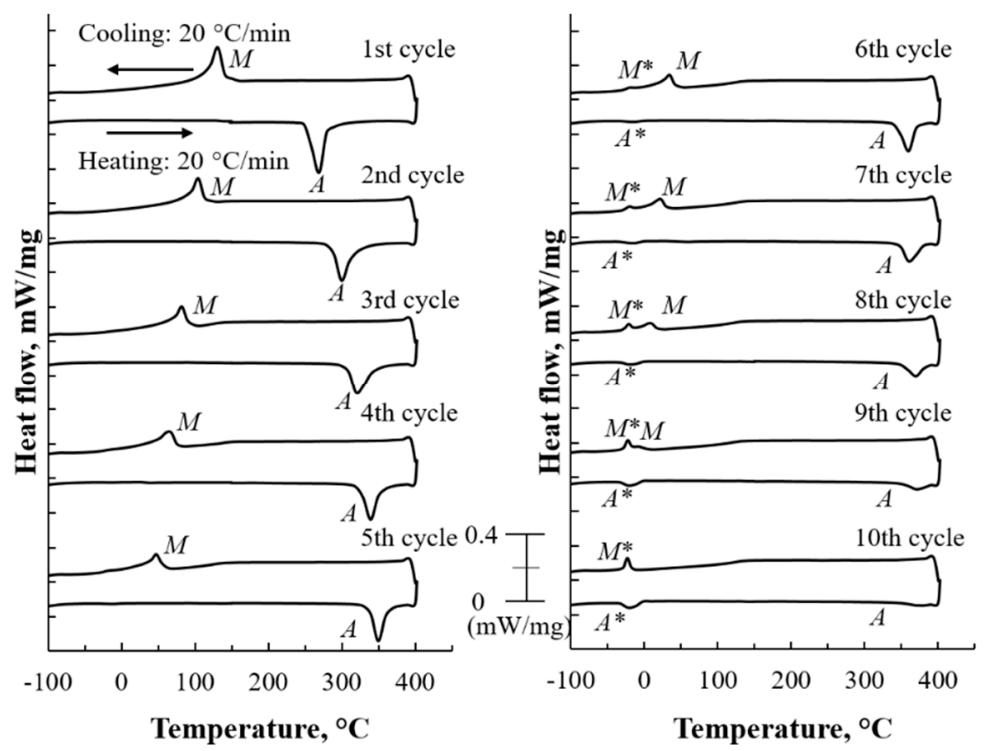

Figure 2. DSC cooling and heating curves of water-quenched equiatomic $\mathrm{CuZr}$ alloy from the first to 10 th thermal cycles. (Measured max temperature- $400^{\circ} \mathrm{C}$ ).

Figures 3 and 4 show the TEM observation results of the 10th cycled equiatomic CuZr alloy. In the bright field image of Figure 3a, many narrow variants with $7-40 \mathrm{~nm}$ in width are observed. The electron diffraction pattern in Figure $3 c$ taken from the boundary $C$ between martensitic variants in (a) indicates $(02 \overline{1})_{C m}$ type I twins along the $[100]_{C m}$ zone axis. A large number of hazy contrasts crossing those variants exist in addition to fine elongated variants in the width of about $7 \mathrm{~nm}$, as indicated by the yellow arrows in Figure $3 b$. The electron diffraction patterns in Figure $3 d$ taken from the area D in (b) indicated additional spots to those associated with the $(02 \overline{1})_{C m}$ type I twins along the $[100]_{C m}$ zone axis. This corresponds to the diffraction spots taken along [021] $]_{C m c a}$ direction of $\mathrm{Cu}_{10} \mathrm{Zr}_{7}$ compound, meaning the presence of $\mathrm{Cu}_{10} \mathrm{Zr}_{7}$ precipitates. The lattice constant of $\mathrm{Cu}_{10} \mathrm{Zr}_{7}$ shows good agreement with the values described in the reference [16,17]: Space group: Cmca, lattice constant: $a=1.269 \mathrm{~nm}$, $b=0.9314 \mathrm{~nm}, c=0.9347 \mathrm{~nm}$. Subsequently, the bright field image of another region in Figure 4a shows the complex contrasts; the lamellar structure with black and white contrasts and almost horizontal linear contrasts indicated by the arrows. The electron diffraction pattern of Figure $4 \mathrm{~b}$ taken from area B in Figure $4 \mathrm{a}$ consists of four sets of reflections. A pair of reflections indicated by the white circles of Figure $4 \mathrm{~b}$ is composed of a pattern of $(001)_{\mathrm{Cm}}$ compound twins along the $[1 \overline{1} 0]_{\mathrm{Cm}}$ zone axis in CuZr martensite, as shown in Figure 4(b-1). The remaining diffraction patterns indicated by the red and yellow circles of Figure $4 \mathrm{~b}$ correspond to the patterns along the [356 $]_{C \text { mca }}$ direction of $\mathrm{Cu}_{10} \mathrm{Zr}_{7}$ and $[\overline{3} 31]_{I 4 / \mathrm{mmm}}$ along the $\mathrm{CuZr_{2 }}$ compounds (space group: $14 / \mathrm{mmm}$, lattice constant: $a=0.3220 \mathrm{~nm}$, $b=0.3220 \mathrm{~nm}, c=1.118 \mathrm{~nm}[18,19])$, as shown in Figure 4(b-2,b-3), respectively. Based on the diffraction intensity of each phase and combination of the various dark-field imaging using diffraction spots originated from each phase, the lamellar structure with black and white contrasts indicates the $\mathrm{Cu}_{10} \mathrm{Zr}_{7}$ and $\mathrm{CuZr}_{2}$ phases, and almost horizontal linear contrasts indicate the CuZr martensite. This lamellar structure is considered that $\mathrm{CuZr}$ matrix experienced eutectoid decomposition into $\mathrm{Cu}_{10} \mathrm{Zr}_{7}$ and $\mathrm{CuZr}_{2}$ phases on the basis of binary $\mathrm{Cu}-\mathrm{Zr}$ phase diagram [20]. This supports that thermal cycling causes the precipitate of $\mathrm{Cu}_{10} \mathrm{Zr}_{7}$ compounds and the eutectoid reaction. Therefore, a shift of the peaks $A$ and $M$ toward the high and low temperature side according to the thermal cycling is originated from the precipitate of $\mathrm{Cu}_{10} \mathrm{Zr}_{7}$ compounds and the eutectoid reaction. 

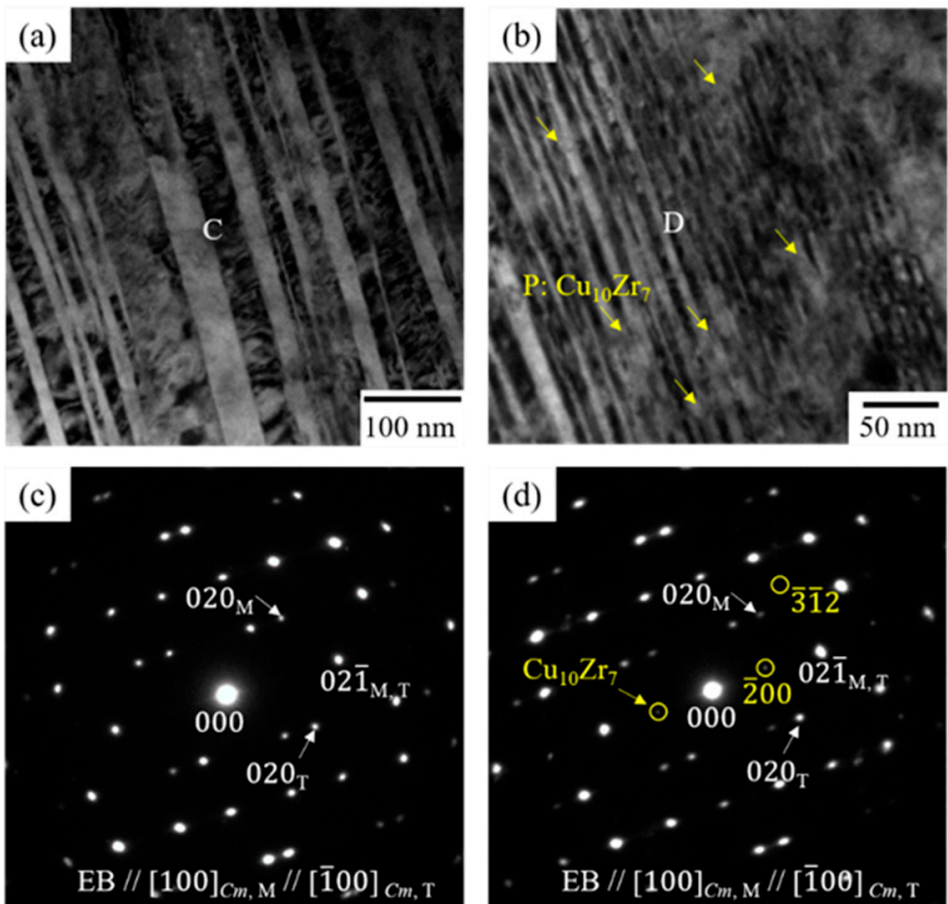

Figure 3. (a,b) Bright field images of 10th cycled equiatomic CuZr alloy, and (c,d) electron diffraction patterns taken from the boundary between martensitic variants in (a) and (b).
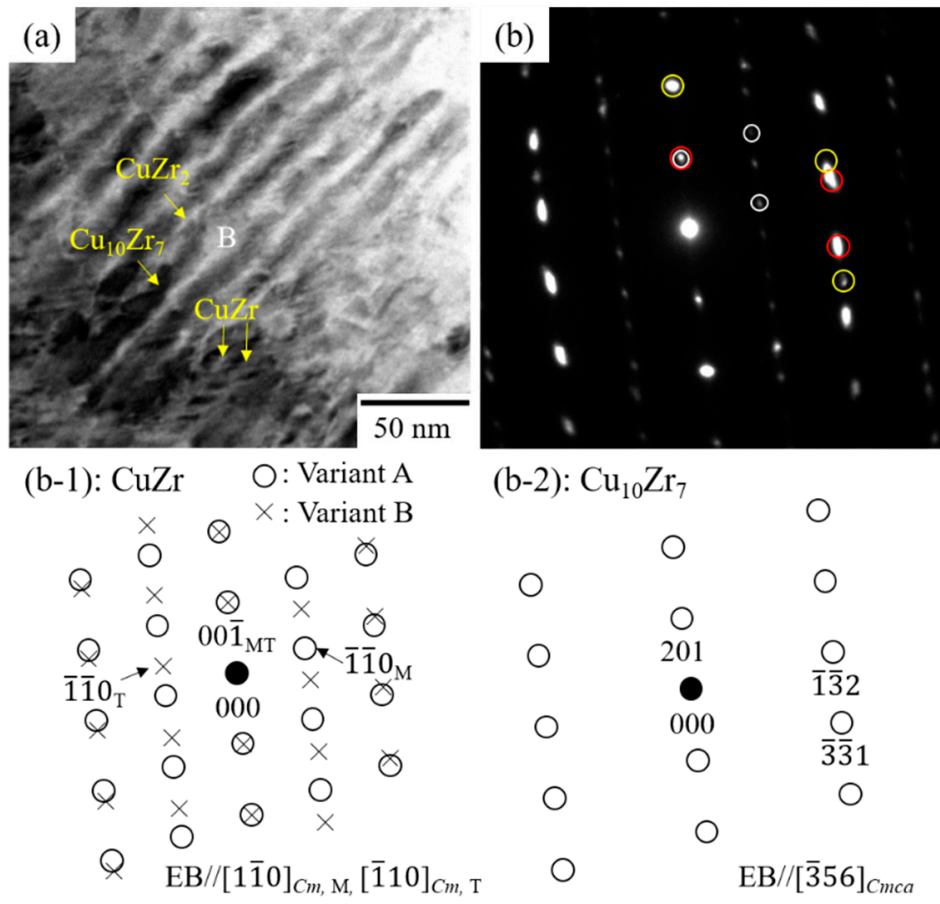

(b-2): $\mathrm{Cu}_{10} \mathrm{Zr}_{7}$

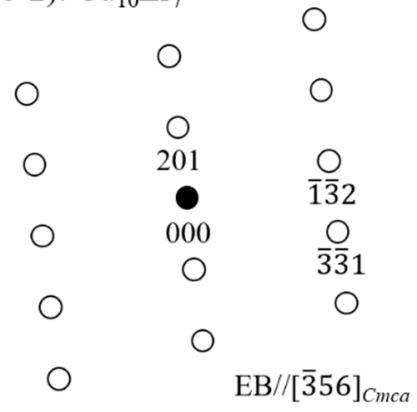

(b-3): $\mathrm{CuZr}_{2}$

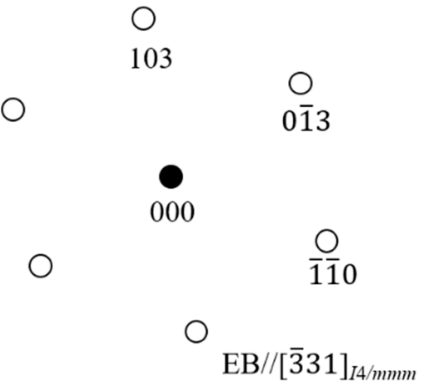

Figure 4. (a) Bright field images of 10th cycled equiatomic CuZr alloy, (b) electron diffraction patterns taken from the (a), and (b-1)-(b-3) schematic of electron diffraction patterns in (c).

\subsection{The Martensitic Transformation Behavior in Equiatomic CuZr Alloy Subjected to Thermal Cycling}

The effects of new peaks $A^{*}$ and $M^{*}$ on the microstructural feature and crystal structure were investigated. First, a thermal cycling test was performed on the 10th cycled equiatomic $\mathrm{CuZr}$ alloy according to the following procedure by DSC measurement; R. T. $\rightarrow-100^{\circ} \mathrm{C} \rightarrow \mathrm{R}$. T. As a result, the 
transformation of $M^{*}$ to $A^{*}$ similar to the 10th cycle in Figure 2 was confirmed, and it was found that there was at least no relationship between the new peaks $M^{*}$ and $M$ which shows from the B2 matrix (space group: $P m \overline{3} m$ ) to the two martensitic phases (space group: $P 2{ }_{1} / m$ and $C m$ ). From this, it is considered that the peak $M^{*}$ is generated by the transformation from the martensitic phases with $C m$ and $P 2_{1} / m$ structure. Firstly, in order to confirm whether $C m$ structure is transformed by new peak $M^{*}$, in-situ cooling TEM observation was performed at the regions which combined with both the precipitates and martensitic structure or existed only martensitic structure. As a result, it was found that there was no difference between the observation at room temperature and $-150{ }^{\circ} \mathrm{C}$ meaning that the region having the $\mathrm{Cm}$ structure was not transformed. From these results, although it has become clear that the precipitates affect the transformation behavior, the new phase cannot be clearly distinguished by the mixture with the precipitate. Therefore, by changing the temperature range of the thermal cycling test by DSC measurement, the amount of precipitates is increased, and we tried to make the microstructure where precipitates and martensite phase were mixed become perfect eutectoid structure.

Figure 5 shows the DSC curves of 10th cycled equiatomic $\mathrm{CuZr}$ alloy with the ranges of measurement temperature were $-100{ }^{\circ} \mathrm{C}$ to $500{ }^{\circ} \mathrm{C}$. It is apparent that peak $A$ and $M$ disappears completely, and new peak $A^{*}$ and $M^{*}$ exists around $-20^{\circ} \mathrm{C}$. Furthermore, Figure 6 shows the DSC curves until 6 th thermal cycles. It is noted that a new peak corresponding to $M^{*}$ appeared at 2 nd cycle, followed by the combination with the peak $M$ at the 3 rd cycle, and then those peaks disappeared at the 6th cycle. These results support the contention that martensitic transformation related to each peak $A$, $M, A^{*}$ and $M^{*}$ are finally inhibited as a eutectoid reaction, due to thermal cycling proceeds. That is, the remaininng martensite with $C m$ and $P 2{ }_{1} / m$ structure except for the precipitated and lamellared regions formed by thermal cycling is considered to be closely associated with the new peak $A^{*}$ and $M^{*}$, and it was found that the new peak of $M^{*}$ was kept to around $-20^{\circ} \mathrm{C}$, due to the formation of precipitates accompanying the thermal cycling test.

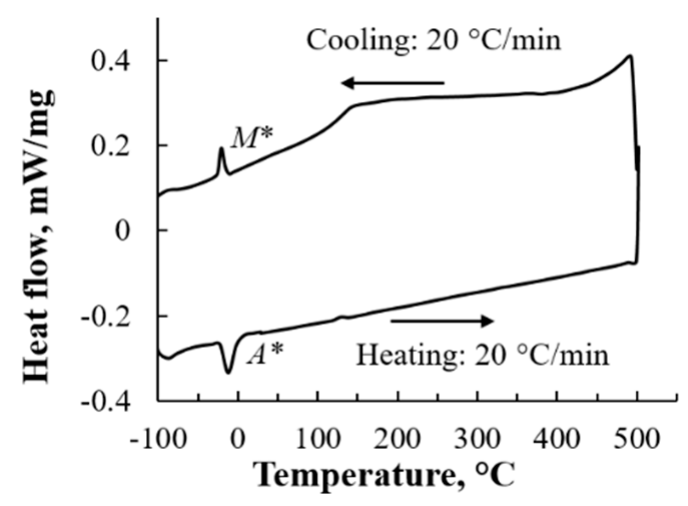

Figure 5. DSC cooling and heating curves of 10th cycled equiatomic $\mathrm{CuZr}$ alloy with maximum temperature of $500{ }^{\circ} \mathrm{C}$. 


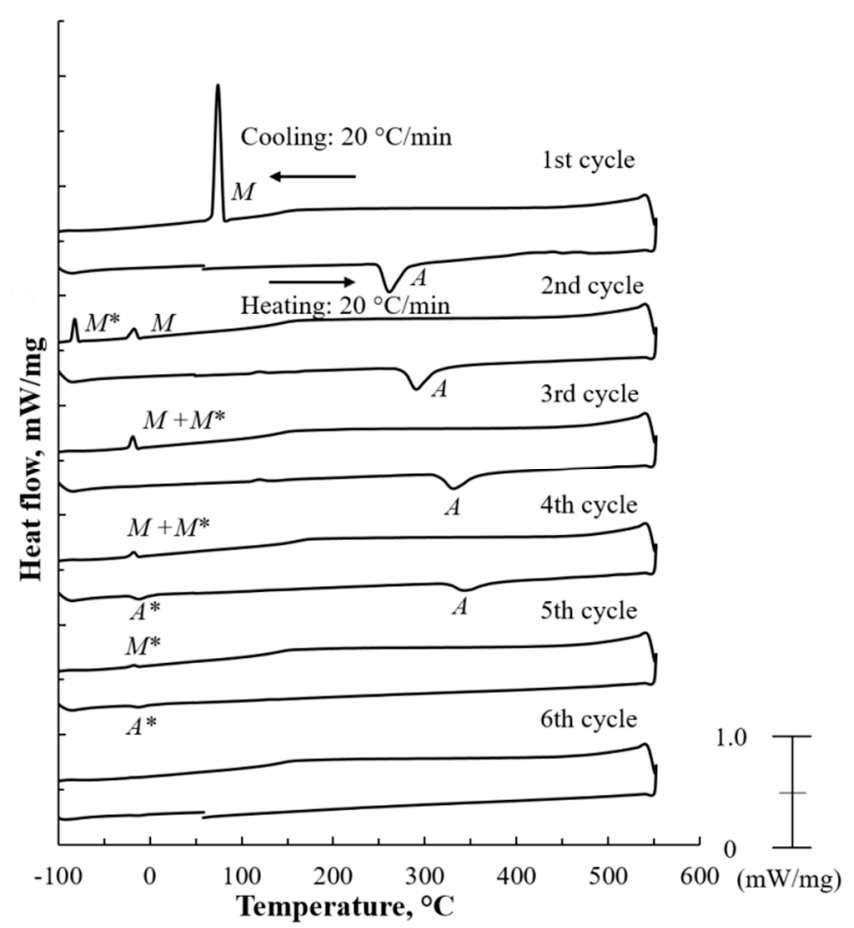

Figure 6. DSC cooling and heating curves of water-quenched equiatomic CuZr alloy from the first to 6th thermal cycles (Measured max temperature- $550{ }^{\circ} \mathrm{C}$ ).

In order to investigate the effect of the thermal cycling test shown in Figures 5 and 6 on the structure, TEM observation was performed. As a result, there were the structures where eutectoid decomposition of $\mathrm{CuZr}$ phase proceeded and did not. Figures 7 and 8 show the results of TEM observation after 10 thermal cycling tests in equiatomic $\mathrm{CuZr}$ alloy by DSC measurement at a maximum temperature of $500{ }^{\circ} \mathrm{C}$. In the bright-field images in Figures 7a and 8a, the only lamellar structure and the only martensitic structure were observed, respectively. The electron diffraction pattern in Figure $7 \mathrm{~b}$ taken from the lamellar structure in (a) consists of three sets of reflections. Two sets of reflection shown in Figure 7(b-1) indicates the patterns stemming from two variants along the $[100]_{\mathrm{Cmca}}$ zone axis in $\mathrm{Cu}_{10} \mathrm{Zr}_{7}$ phase. The remaining pattern is composed of the diffraction pattern from the $[0 \overline{1} 0]_{14} / \mathrm{mmm}$ zone axis in $\mathrm{CuZr}_{2}$, as shown in Figure 7(b-2). The orientation relationship between $\mathrm{Cu}_{10} \mathrm{Zr}_{7}$ and $\mathrm{CuZr}_{2}$ was $[100]_{\text {Cmca }} / /[010]_{I 4} /{ }_{m m m} ;(011)_{C m c a} / /(001)_{I 4} / m m m$. In-situ cooling TEM observation was performed in this fully lamellered structure, providing that no microstructural changes were observed by cooling to $-150{ }^{\circ} \mathrm{C}$ below peak $M^{*}$ as expected. In addition, TEM observation after the thermal cycling test in Figure 6 shows that the eutectoid structure is totally formed. Therefore, we focused on the remaining martensitic regions after 10th thermal cycling. 


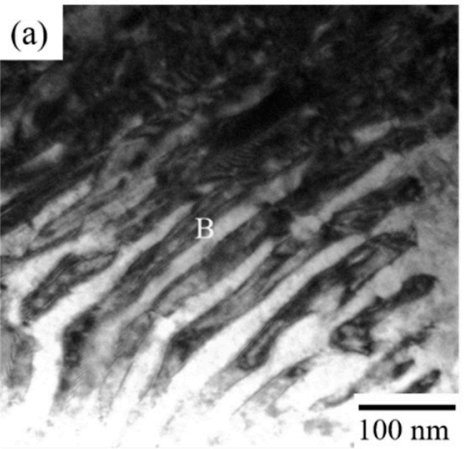

(b-1) $\mathrm{O}: \mathrm{Cu}_{10} \mathrm{Zr}_{7}$ Variant $\mathrm{A}$ Variant B

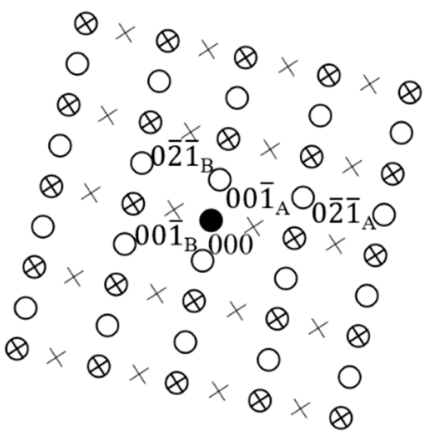

$\mathrm{EB} / /[100]_{\text {Cmca. } \mathrm{Cu}_{10} \mathrm{Zr}_{7}}$ (b) ${ }^{\circ}: \mathrm{Cu}_{10} \mathrm{Zr}_{7}$ Variant $\mathrm{A} \square ;{ }^{\circ} \mathrm{CuZr}_{2}$

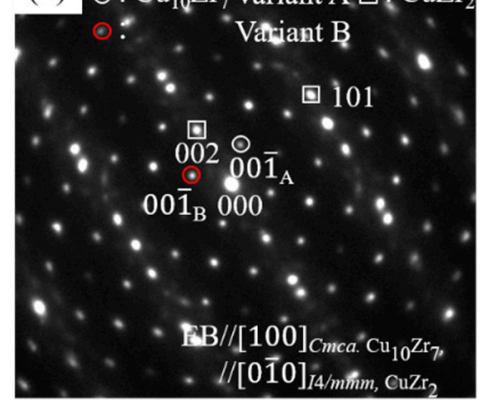

(b-2) $\square: \mathrm{CuZr}_{2}$

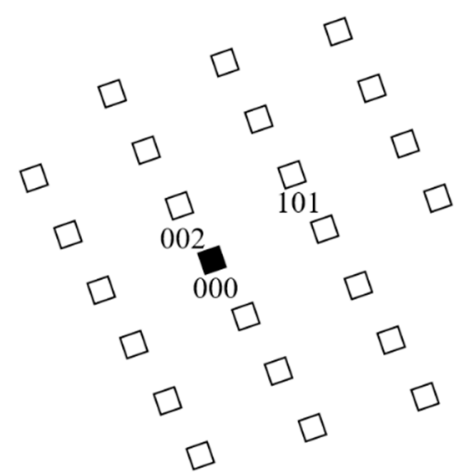

$\mathrm{EB} / /[0 \overline{1} 0]_{14 / m m m, \mathrm{CuZr}_{2}}$

Figure 7. (a) Bright field image of 10th cycled equiatomic CuZr alloy, (b) electron diffraction pattern is taken from the (a), and (b-1)-(b-2) schematic of electron diffraction patterns in (b). (The measured maximum temperature at DSC measurement is $500{ }^{\circ} \mathrm{C}$.).
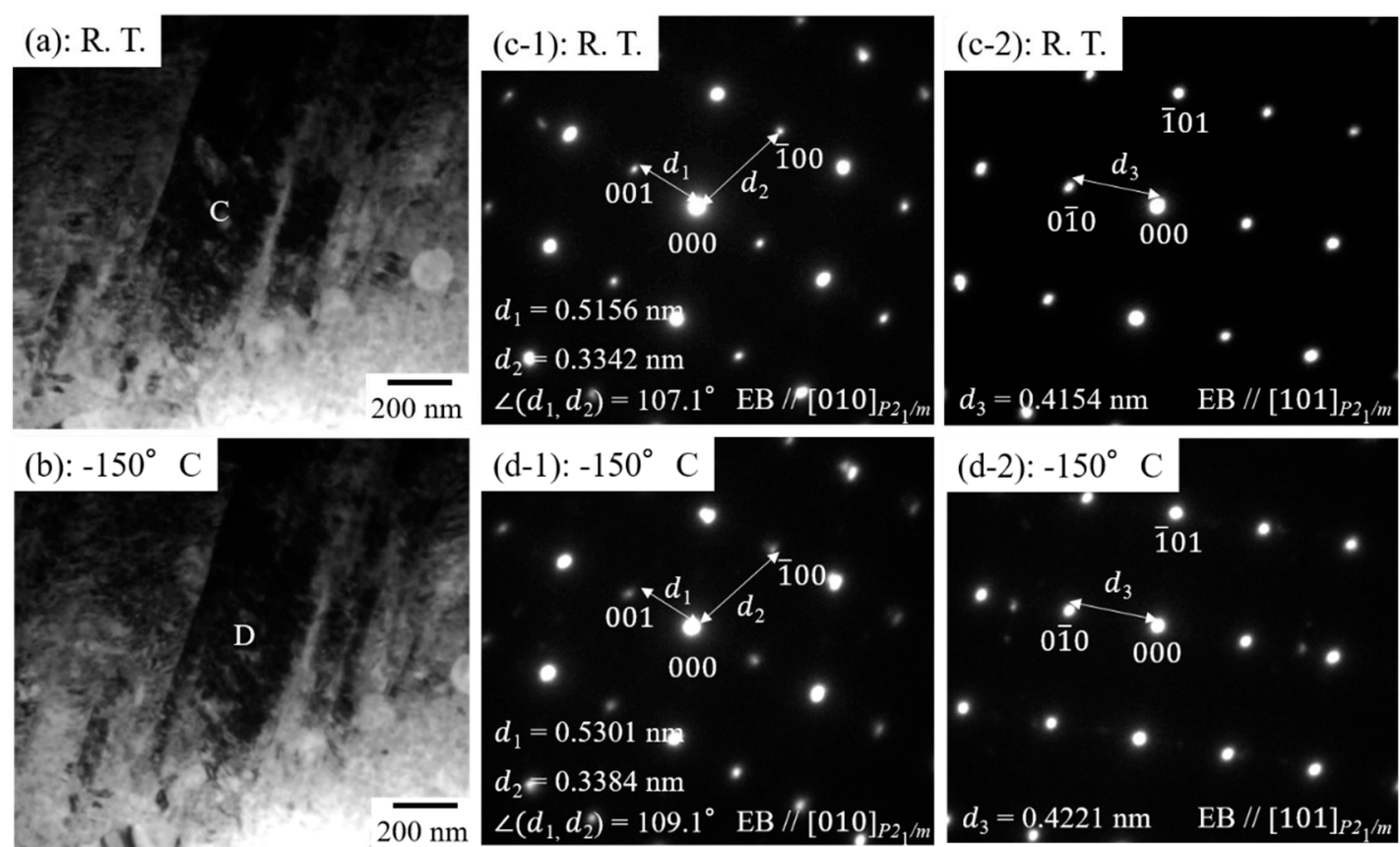

Figure 8. (a,b) Bright field images of 10th cycled equiatomic $\mathrm{CuZr}$ alloy at R. T., and $-150{ }^{\circ} \mathrm{C}$, and $(\mathbf{c}-\mathbf{1}, \mathbf{2})-(\mathbf{d}-\mathbf{1}, \mathbf{2})$ electron diffraction patterns taken from the martensitic variants $C$ in $(\mathbf{a})$, and $D$ in (b), respectively. (The measured maximum temperature at DSC measurement is $500{ }^{\circ} \mathrm{C}$ ). 
Figure 8 shows the TEM images of in-situ cooling observation from room temperature to $-150{ }^{\circ} \mathrm{C}$. The electron diffraction patterns in Figure $8(\mathrm{c}-1, \mathrm{c}-2)$ taken from the martensitic variant in (a) indicated the $[010]_{P 21 / m}$ and $[101]_{P 21 / m}$ zone axes in CuZr. The lattice constants of $P 2_{1} / m$ in 10 th thermal cycled specimen is estimated as $a=0.334 \mathrm{~nm}, b=0.415 \mathrm{~nm}, c=0.516 \mathrm{~nm}, \beta=107.1^{\circ}$ from electron diffraction patterns. Compared with those of the water-quenched specimen, which are $a=0.331 \mathrm{~nm}, b=0.421$ $\mathrm{nm}, c=0.525 \mathrm{~nm}, \beta=104.2^{\circ}$, these values are a little difference. This should be due to the difference in the alloy composition of matrix accompanying eutectoid decomposition by thermal cycling test. Figure $8 \mathrm{~b}$ shows the bright field image in the same location as (a) in the specimen cooled until $-150{ }^{\circ} \mathrm{C}$. No change of morphology of martensitic variant was observed between R. T. and $-150{ }^{\circ} \mathrm{C}$. However, it is noted that $d$ values and the angle between planes shown in Figure $8(d-1, d-2)$ are much different from those of Figure $8(\mathrm{c}-1, \mathrm{c}-2)$. Based on the electron diffraction patterns taken from another martensitic variant at $-150{ }^{\circ} \mathrm{C}$, the lattice constants of martensite at $-150{ }^{\circ} \mathrm{C}$ are $a^{\prime}=0.338 \mathrm{~nm}, b^{\prime}=0.422 \mathrm{~nm}$, $c^{\prime}=0.530 \mathrm{~nm}, \beta^{\prime}=109.1^{\circ}$. Comparing the change of the lattice constant at room temperature and $-150{ }^{\circ} \mathrm{C}$, the results are $a^{\prime}=a+0.004 \mathrm{~nm}, b^{\prime}=b+0.007 \mathrm{~nm}, c^{\prime}=c+0.014 \mathrm{~nm}, \beta^{\prime}=\beta+2.0^{\circ}$. These results indicate that $c$-axis and $\beta$ angle move largely, and $a$ - and $b$-axes hardly move. Figure 9 shows the schematic illustration of a unit cell showing change of the lattice constant accompanying with heating and cooling. Usually, the metals are known to shrink during cooling. However, the change of the lattice constant obtained from present in-situ cooling observation was not shrinking but expanding of a unit cell. From the above results, the change of the lattice constant, due to cooling is associated with the new peak $M^{*}$, that is, new martensitic transformation around $-20{ }^{\circ} \mathrm{C}$. From the change of the lattice constant, it is clear that the $c$-axis and $\beta$ angle largely moved compared to $a$ - and $b$-axes through the new martensitic transformation, and it is predicted that the atoms existed in the (110) $)_{\mathrm{B} 2}$ plane in B2 parent phase have moved further, as indicated by the arrows of the schematic diagram at $-150{ }^{\circ} \mathrm{C}$ in Figure 9. Ti-Ni and Ti-Pt alloys [21,22] which is one of shape memory alloys have the shear-shuffling mechanism of $(110)[1 \overline{1} 0]_{\mathrm{B} 2}$ in general, supporting that this new martensitic transformation is caused by the further movement of the $(110)_{\mathrm{B} 2}$ plane in B2 parent phase; that is, the significant change of $c$-axis and $\beta$ angle. Furthermore, small transformation strain evaluated from the change of lattice constants seen in Figure 9 provides the small thermal hysteresis of the new peaks $M^{*}$ and $A^{*}$, leading to the no change of morphology in the whole variants compared with Figure $8 \mathrm{a}, \mathrm{b}$. This new martensitic transformation at low temperature is considered to be closely related to the strain and stress caused by thermal cycling. During this new martensitic transformation, the $P 2_{1} / m$ structure was transformed instead of the $\mathrm{Cm}$ structure. Concerning the crystal structure of new martensite at low temperature, $P 2$ or $P 2_{1}$ which is a subgroup of $P 2_{1} / m$ is mentioned as an option of the space group. Otherwise, it might indicate a tendency to further transformation from the $P 2_{1} / m$ structure to $C m$ structure by strain and stress, due to thermal cycling. Although the amount of deformation of this new martensite caused by thermal cycling is so small, the transformation temperature keeps constant below room temperature, and the thermal hysteresis is much small. Materials design for controlling this new martensitic transformation behavior accompanied by thermal cycling and training treatment could be possible to lead to the shape memory alloy of low temperature type in the future. 
R. T.

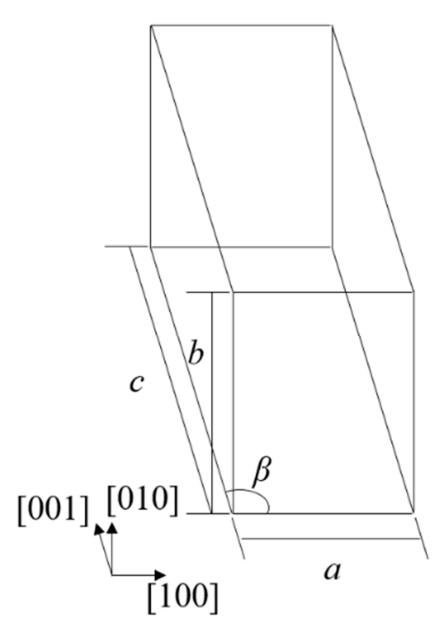

$a=0.334 \mathrm{~nm}, b=0.415 \mathrm{~nm}$, $c=0.516 \mathrm{~nm}, \beta=107.1^{\circ}$ $-150^{\circ} \mathrm{C}$

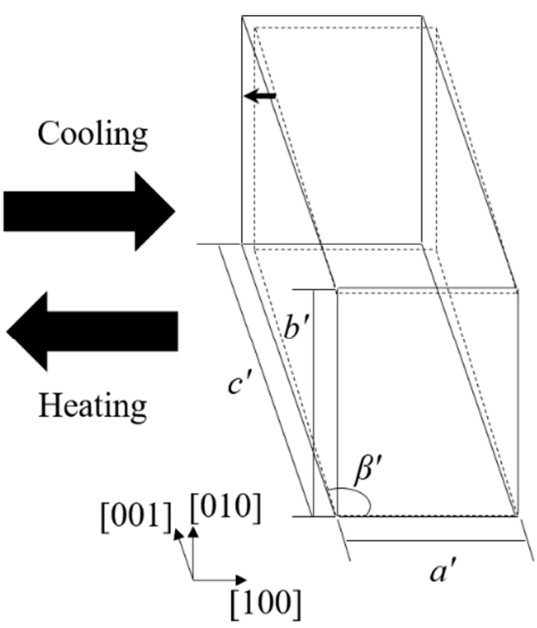

$a^{\prime}=0.338 \mathrm{~nm}, b^{\prime}=0.422 \mathrm{~nm}$, $c^{\prime}=0.530 \mathrm{~nm}, \beta^{\prime}=109.1^{\circ}$

Figure 9. The change of lattice constant in the martensitic phase (R. T.) to the new phase $\left(-150{ }^{\circ} \mathrm{C}\right)$ of 10th cycled CuZr alloy.

\section{Conclusions}

In this study, we investigated the microstructure and martensitic transformation behavior in thermal cycled equiatomic $\mathrm{CuZr}$ shape memory alloy using TEM. The obtained results are summarized as follows.

1. In the 10th cycled equiatomic CuZr alloy (the temperature range of DSC measurement: $-100^{\circ} \mathrm{C}$ to $400^{\circ} \mathrm{C}$ ), three structures were observed by TEM; I: The martensitic variant, II: The structure in which $\mathrm{Cu}_{10} \mathrm{Zr}_{7}$ precipitates exist inside the martensitic variant, III: The structure in which the lamellar consisting of $\mathrm{Cu}_{10} \mathrm{Zr}_{7}$ and $\mathrm{CuZr}_{2}$ phases and martensitic variants are mixed. TEM observation of the 10th cycled equiatomic CuZr alloy (the temperature range of DSC measurement: $-100^{\circ} \mathrm{C}$ to $500^{\circ} \mathrm{C}$ ) showed two structures; I: The martensitic variant, II: The lamellar structure in which the $\mathrm{CuZr}$ martensitic phase was completely eutectoid transformed. This fact indicated that the eutectoid decomposition occurred in equiatomic $\mathrm{CuZr}$ alloy during the thermal cycling.

2. When the martensitic variant having $P 2_{1} / m$ (lattice constant: $a=0.334 \mathrm{~nm}, b=0.415 \mathrm{~nm}$, $c=0.516 \mathrm{~nm}, \beta=107.1^{\circ}$ ) of 10th cycled equiatomic $\mathrm{CuZr}$ alloy was cooled from room temperature to $-150{ }^{\circ} \mathrm{C}$, the change in the crystal structure corresponding to the new peak $M^{*}$ occurred, and the lattice constant was $a^{\prime}=0.338 \mathrm{~nm}, b^{\prime}=0.422 \mathrm{~nm}, c^{\prime}=0.530 \mathrm{~nm}, \beta^{\prime}=109.1^{\circ}$. This new martensitic transformation at low temperature is considered to be closely related to the strain and stress caused by thermal cycling.

Author Contributions: S.H., M.M., and M.N. conceived and designed the experiments; S.H and M.M. performed the experiments, analyzed the data, wrote original draft preparation; M.N., C.A.B., and A.T. wrote review and editing.

Conflicts of Interest: The authors declare no conflict of interest.

\section{References}

1. Carvalho, E.M.; Harris, I.R. Constitutional and structural studies of the intermetallic phase, ZrCu. J. Mater. Sci. 1980, 15, 1224-1230. [CrossRef]

2. Koval, Y.N.; Firstov, G.S.; Kotko, A.V. Martensitic transformation and shape memory effect in $\mathrm{ZrCu}$ intermetallic compound. Scr. Metall. Mater. 1992, 27, 1611-1616. [CrossRef] 
3. Schryvers, D.; Firstov, G.S.; Seo, J.W.; Van Humbeeck, J.; Koval, Y.N. Unit cell determination in CuZr martensite by electron microscopy and X-ray diffraction. Scr. Mater. 1997, 36, 1119-1125. [CrossRef]

4. Seo, J.W.; Schryvers, D. TEM investigation of the microstructure and defects of CuZr martensite. Part I: Morphology and twin systems. Acta Mater. 1998, 46, 1165-1175. [CrossRef]

5. Seo, J.W.; Schryvers, D. TEM investigation of the microstructure and defects of CuZr martensite. Part II: Planar defects. Acta Mater. 1998, 46, 1177-1183. [CrossRef]

6. Firstov, G.S.; Van Humbeeck, J.; Koval, Y.N. High-temperature shape memory alloys some recent developments. Mater. Sci. Eng. A 2004, 378, 2-10. [CrossRef]

7. Zhou, S.H.; Napolitano, R.E. Identification of the B33 martensite phase in Cu-Zr using first-principles and X-ray diffraction. Scr. Mater. 2008, 59, 1143-1146. [CrossRef]

8. Song, K.K.; Pauly, S.; Zhang, Y.; Gargarella, P.; Li, R.; Barekar, N.S.; Kühn, U.; Eckert, J. Strategy for pinpointing the formation of B2 CuZr in metastable CuZr-based shape memory alloys. Acta Mater. 2011, 59, 6620-6630. [CrossRef]

9. Meng, X.; Gao, W.; Gao, Z.; Cai, W.; Zhao, L. Substructure and interface of the superstructure martensite in $\mathrm{Zr}_{50} \mathrm{Cu}_{50}$ High temperature shape memory alloy. Mater. Lett. 2014, 117, 221-224. [CrossRef]

10. Biffi, C.A.; Figini, A.; Tuissi, A. Influence of compositional ratio on microstructure and martensitic transformation of CuZr shape memory alloys. Intermetallics 2014, 46, 4-11. [CrossRef]

11. Gao, W.; Yi, X.; Sun, B.; Meng, X.; Cai, W.; Zhao, L. Microstructural evolution of martensite during deformation in $\mathrm{Zr}_{50} \mathrm{Cu}_{50}$ shape memory alloy. Acta Mater. 2017, 132, 405-415. [CrossRef]

12. Biffi, C.A.; Coduri, M.; Yoshida, H.; Soejima, Y.; Nishida, M.; Tuissi, A. The effect of thermal cycling on the martensitic transformation in equiatomic CuZr shape memory alloy. J. Alloy. Compd. 2015, 653, 591-595. [CrossRef]

13. Hubbard, C.R.; Evans, E.H.; Smith, D.K. The reference intensity ratio, $I / I_{\mathcal{C}}$, for computer simulated powder patterns. J. Appl. Cryst. 2002, 9, 169-174. [CrossRef]

14. Kosorukova, T.; Firstov, G.; Koval, Y.; Verhovlyuk, P.; Van Humbeeck, J.; Noel, H. Structural phase transformations and shape memory effect in $\mathrm{ZrCu}$ along with $\mathrm{Ni}$ and $\mathrm{Hf}$ additions. MATEC Web Conf. 2015, 33, 06005. [CrossRef]

15. Pawley, G.S. Unit-cell refinement from powder diffraction scans. J. Appl. Crystallogr. 1981, 14, 357-361. [CrossRef]

16. Glimois, J.L.; Forey, P.; Feron, J.; Becle, C. Structural investigations of the pseudo-binary compounds $\mathrm{Ni}_{10-\mathrm{x}} \mathrm{Cu}_{\mathrm{x}} \mathrm{Zr}_{7}$. J. Less Common Met. 1981, 78, 45-50. [CrossRef]

17. Biffi, C.A.; Figini, A.; Tuissi, A. Synthesis and structural analysis of $\mathrm{Cu}_{10} \mathrm{Zr}_{7}$. J. Alloy. Compd. 2012, 544, 42-45.

18. Du, J.; Wen, B.; Melnik, R.; Kawazoe, Y. Phase stability, elastic and electronic properties of Cu-Zr binary system intermetallic compounds: A first-principles study. J. Alloy. Compd. 2014, 588, 96-102. [CrossRef]

19. Bykov, V.A.; Kulikova, T.V.; Yagodin, D.A.; Filippov, V.V.; Shunyaev, K.Y. Thermophysical and electrical properties of equiatomic CuZr alloy. Phys. Met. Metallogr. 2015, 116, 1067-1072. [CrossRef]

20. Zhao, Y.; Pang, T.; He, J.; Tao, X.; Chen, H.; Ouyang, Y.; Du, Y. Interdiffusion behaviors and mechanical properties of Cu-Zr system. Calphad 2018, 61, 92-97. [CrossRef]

21. Otsuka, K.; Ren, X. Recent developments in the research of shape memory alloys. Intermetallics 1999, 7, 511-528. [CrossRef]

22. Rotaru, G.M.; Tirry, W.; Sittner, P.; Van Humbeeck, J.; Schryvers, D. Microstructural study of equiatomic PtTi martensite and the discovery of a new long-period structure. Acta Mater. 2007, 55, 4447-4454. [CrossRef]

(C) 2019 by the authors. Licensee MDPI, Basel, Switzerland. This article is an open access article distributed under the terms and conditions of the Creative Commons Attribution (CC BY) license (http://creativecommons.org/licenses/by/4.0/). 